\title{
Recurrent Nasal Cavity and Paranasal Sinus Squamous Cell Carcinoma
}

National Cancer Institute

\section{Source}

National Cancer Institute. Recurrent Nasal Cavity and Paranasal Sinus Squamous Cell

Carcinoma. NCl Thesaurus. Code C115443.

The reemergence of nasal cavity and paranasal sinus squamous cell carcinoma after a period of remission. 